\title{
Peningkatan Keterampilan Menceritakan Kembali Isi Cerpen dengan Menerapkan Strategi Pembelajaran Think Talk Write pada Siswa SMP Negeri 1 Selesai Tahun Ajaran 2016/2017
}

\section{Ulina Marinetty Marbun}

SMP Negeri 1 Selesai, Langkat, Sumatera Utara, Indonesia

E-mail: ulinamarbun@gmail.com

\begin{abstract}
Abstrak
Tujuan penelitian ini adalah peningkatan keterampilan siswa dalam menceritakan kembali isi cerpen dengan strategi pembelajaran Think Talk Write pada siswa SMP Negeri 1 Selesai tahun ajaran 2016/2017. Penelitian ini merupakan penelitian tindakan kelas dengan metode penelitian deskriptif kualitatif yang terdiri dari 2 siklus. Setiap siklus terdiri atas 4 tahap yaitu, perencanaan, pelaksanaan, pengamatan dan refleksi. Metode pengumpulan data yang digunakan dalam penelitian ini adalah hasil pengamatan di lapangan dalam lembar observasi. Adapun yang menjadi subjek penelitian adalah siswa kelas IX-6 SMP Negeri 1 Selesai terdiri dari 32 siswa. Pada siklus I belum semua siswa terbiasa dengan strategi pembelajaran Think Talk Write yang diterapkan dalam menceritakan kembali isi cerpen. Hal ini dapat dilihat dari nilai rata-rata yang diperoleh siswa, pada siklus awal yaitu 75,2 dengan persentase $71,9 \%$. Pada Siklus II, siswa mulai memahami strategi pembelajaran Think Talk Write dalam menceritakan kembali isi cerpen. Hal ini dapat dilihat dari nilai hasil belajar yang mengalami peningkatan yaitu 82,8 dengan persentase sebesar 90,6\%. Dalam hal ini dapat kita simpulkan bahwa keterampilan siswa dalam menceritakan kembali isi cerpen meningkat.
\end{abstract}

Kata Kunci : Keterampilan, Cerpen, Think Talk Write

\section{Abstract}

The purpose of this study is to improve the student's skills in retelling the contents of the short story with Think Talk Write learning on students of SMP Negeri 1 Selesai academic year 2016/2017. This research is a classroom action research with qualitative descriptive research method consisting of 2 cycles. Each cycle consists of 4 stages namely, planning, implementation, observation and reflection. Data 
collection method used in this research is the result of observation in the field in the observation sheet. As the subject of the research is the students of class IX-6 SMP Negeri 1 Selesai consists of 32 students. In the first cycle, not all students are familiar with the Think Talk Write learning applied in retelling the contents of the short story. This can be seen from the average value obtained by students, in the early cycle of 75.2 with percentage of $71.9 \%$. In Cycle II, students begin to understand the Think Talk Write learning strategy in retelling the contents of the short story. This can be seen from the value of learning outcomes that experienced an increase of 82.8 with a percentage of 90.6\%. In this case, we can conclude that the students' skills in retelling the content of the short story is increased.

Keywords: Skills, Short Stories, Think Talk Write

\section{A. PENDAhuluan}

Pendidikan yang mampu mendukung pembangunan di masa mendatang adalah pendidikan yang mampu mengembangkan potensi peserta didik dan kualitas pembelajaran. Peningkatan kualitas pembelajaran merupakan salah satu peningkatan mutu pendidikan secara keseluruhan. Upaya peningkatan mutu pendidikan adalah bagian terpadu dari upaya peningkatan kualitas manusia, baik aspek kemampuan, kepribadian maupun tanggung jawab sebagai warga negara.

Kurikulum KTSP atau Tingkat Satuan Pendidikan tahun 2006 hasil pengembangan dari KBK yang berkualitas standar menuntut adanya pengembangan proses pembelajaran dengan menggunakan strategi pembelajaran inovasi sehingga proses pembelajaran dapat dilaksanakan sesuai dengan tuntutan kurikulum sangatlah diperlukan.

Keterampilan berbahasa yang diajarkan kepada siswa SMP terdiri atas keterampilan reseptif maupun produktif. Hal ini sesuai dengan pendapat Tarigan (1994:1) bahwa keterampilan berbahasa mencakup empat segi yaitu menyimak (Listening Skill), berbicara (Speacking Skill), membaca (Reading Skill), dan menulis (Writing Skill). Selain keterampilan membaca, keterampilan menulis merupakan satu dari keempat keterampilan berbahasa yang diajarkan kepada peserta didik yang belajar bahasa, salah satunya menceritakan kembali isi cerpen melalui mengarang. 
Kegiatan berbicara dilakukan seseorang setiap hari paling tidak untuk memenuhi kebutuhannya sebagai manusia dalam peristiwa apapun. Karena keterampilan berbicara sudah terbiasa dilakukan dalam pembelajaran kompetensi tersebut siswa dapat $75 \%$ tuntas hasil pembelajarannya. Namun, kenyataannya di kelas IX-6 SMP Negeri 1 Selesai Tahun Pelajaran 2016/2017 pada kompetensi dasar menceritakan kembali isi cerpen hanya mencapai 55\%. Dengan demikian, di kelas tersebut dapat dikatakan tidak tuntas secara klasikal.

Berdasarkan hasil observasi awal di kelas IX-6 SMP Negeri 1 Selesai Tahun Pelajaran 2016/2017 beberapa siswa masih sulit untuk mengemukakan ide, pikiran, atau gagasan ke dalam bentuk kata-kata. Kendala yang dihadapi siswa antara lain, rasa malu, gerogi, dan tidak berani siswa untuk mengutarakan gagasan, ide, atau pendapatnya dalam kegiatan bercerita, proses berbicara masih banyak siswa yang kurang serius dan aktif dalam proses pembelajaran bercerita.

Melihat semua permasalahan yang ada pada siswa kelas IX-6 SMP Negeri 1 Selesai Tahun Pelajaran 2016/2017, perlu digunakan strategi pembelajaran yang menarik agar mampu meningkatkan proses pembelajaran bercerita siswa. Pemecahan masalah inilah yang mendasari untuk dilakukan penelitian. Sebagai salah satu alternatif pemecahan masalah tersebut, diajukan strategi. Salah satu strategi pembelajaran yang dapat digunakan adalah Think Talk Write (TTW) yang dapat membantu meningkatkan proses keterampilan bercerita. Pembelajaran dengan strategi Think Talk Write (TTW) diharapkan dapat meningkatkan proses dan hasil kegiatan bercerita sesuai dengan kompetensi dasar yang harus dicapai siswa.

Pembelajaran Think Talk Write (TTW) membangun pemikiran, merefleksi, mengorganisasi ide, kemudian menguji ide tersebut sebelum peserta didik diharapkan untuk menulis. Alur strategi pembelajaran Think Talk Write (TTW) dimulai dari keterlibatan peserta didik dalam berpikir atau berdialog reflektif dengan dirinya sendiri, selanjutnya berbicara dan berbagi ide dengan temannya, sebelum peserta didik menulis.

Pada artikel ini akan menganalisis apakah keterampilan menceritakan kembali isi cerpen melalui penerapan pembelajaran Think Talk Write pada siswa SMP Negeri 1 Selesai meningkat. 


\section{B. TINJAUAN PUSTAKA}

\section{Bentuk-bentuk Keterampilan Berbicara}

Dalam kemampuan berbicara terdapat beberapa bentuk kegiatan berbicara yang dapat digunakan guru untuk melatih kegiatan berbicara siswa. Bentuk keterampilan berbicara yang utama dalam penelitian ini adalah bercerita.

Penelitian ini menggunakan kegiatan bercerita sebagai penilaian untuk mengetahui tingkat perkembangan keterampilan berbicara siswa. Sementara itu, bentuk-bentuk kegiatan berbicara menurut Nurgiyantoro (1995: 276-289) adalah berbicara berdasarkan gambar, menceritakan kembali, bercerita, pidato, diskusi,

\section{Bercerita}

Pembelajaran keterampilan bercerita adalah pembelajaran yang mampumengembangkan keterampilan siswa dalam berbicara. Keterampilan berbicara bukanlah sesuatu yang dapat diajarkan melalui uraian dan penjelasan guru saja. Akan tetapi, siswa harus dihadapkan pada kegiatan nyata yang menggunakan bahasa sebagai alat komunikasi dalam berbagai konteks komunikasi.

Pembelajaran bercerita merupakan bagian yang tidak dapat dipisahkan dari keterampilan berbicara. Menurut Nurgiyantoro (2012, 288-289), bercerita merupakan salah satu tugas kemampuan atau kegiatan berbicara yang dapat mengungkapkan kemampuan berbicara siswa yang bersifat pragmatis. Ada dua unsur penting yang perlu dikuasai siswa, yaitu unsur linguistik (bagaimana cara bercerita, bagaiman memilih bahasa) dan unsur "apa yang diceritakan. Ketepatan, kelancaran, dan kejelasan cerita akan menunjukkan kemampuan berbicara siswa.

Oleh karena itu, keterampilan bercerita pada siswa perlu ditingkatkan melaluipelatihan bercerita secara teratur, sistematis, dan berkesinambungan. Menurut Tim Penyusun Pusat Bahasa (2007: 210), cerita adalah tuturan yang membentangkan terjadinya suatu hal (peristiwa, kejadian), karangan yang menuturkan perbuatan, pengalaman (penderitaan orang), kejadian yang nyata atau rekaan. Berdasarkan tinjauan linguistik bercerita berasal dari kata dasar cerita yang mendapatkan awalan (ber-) memiliki makna melakukan suatu tindakan. 
Dariuraian di atas dapat disimpulkan bahwa bercerita adalah suatu kegiatan yang menjelaskan terjadinya suatu hal, peristiwa dan kejadian yang dialami sendiri ataupun orang lain. Kegiatan bercerita dapat memberikan hiburan dan merangsang imajinasi siswa. Kegiatan bercerita dapat menambah keterampilan bahasa lisan siswa secara terorganisasi.

\section{Faktor-faktor yang Mempengaruhi Keterampilan Bercerita}

Berkaitan dengan kegiatan bercerita sebagai salah satu indikasikemampuan berbicara siswa, Sudarmaji, dkk. (2010: 27-32) mengungkapkanbahwa untuk mencapai keberhasilan dalam bercerita, ada dua faktor pokok yang harus diperhatikan oleh setiap pendidik yang akan bercerita, yaitu naskah atau skenario atau setidaknya sinopsis (kerangka cerita) dan teknik penyajian.

Nurgiyantoro (2012: 289) mengatakan, ada dua unsur penting yang harus dikuasaisiswa dalam bercerita yaitu linguistik dan unsur apa yang diceritakan. Ketepatan ucapan, tata bahasa, kosakata, kefasihan dan kelancaran, menggambarkan bahwa siswa memiliki kemampuan bercerita yang baik. Agar penceritaan menjadi bagus dan disukai pendengar maka proses penceritaan perlu adanya hal-hal yang mencakup bahasa, suara, gerakan-gerakan, peragaan, dan peristiwaperistiwa (Majid, 2008: 9).

Penceritaan atau bercerita dengan bahasa, suara, gerakan, dan ekspresi yang bagus akan menampakkan gambaran lebih hidup di hadapan pendengar. Sebaliknya, penceritaan yang buruk akan menghilangkan apa yang seharusnya menarik dalam cerita (Majid, 2008: 28). Jokobovits dan Gordon (dalam Nurgiyantoro, 2012) menyebutkan bahwa kemampuan bercerita meliputi keakuratan informasi, ketepatan struktur dan kosakata, kelancaran, kewajaran urutan wacana, dan gaya pengucapan. Komponen tersebut merupakan modifikasi dari faktor-faktor yang dinilai dalam berpidato.

Dari beberapa faktor tersebut yang menjadi indikator kemampuan bercerita anak SMP adalah pelafalan, pilihan kata, struktur, intonasi, sikap, kelancaran, gerak-gerik dan mimic, kemampuan mengembangkan cerita.

Disimpulkan bahwa seorang pencerita harus pandai mengembangkan berbagai unsur penyajian cerita. Ada dua unsur penting yangharus dikuasai siswa dalam bercerita yaitu linguistik dan 
unsur apa yangdiceritakan. Ketepatan ucapan, tata bahasa, kosakata, kefasihan dan kelancaran, menggambarkan bahwa siswa memiliki kemampuan bercerita yang baik.

\section{Cerpen}

Cerpen (cerita pendek) adalah karangan pendek yang berbentuk prosa. Struktur cerpen dibentuk oleh unsur-unsur berikut: tema adalah inti atau ide dasar sebuah karangan; alur/Plot adalah bagian dari unsur intrinsik yang merupakan jalan cerita yang diemban oleh masing-masing tokoh dalam cerita; setting/Latar yaitu tempat, waktu, dan suasana yang melatari sebuah cerita; tokoh dan karakterisasi ialah tokoh yang diceritakan dalam cerita dengan dilengkapi sebuah watak dalam dirinya; tokoh dan karakter merupakan satu kesatuan yang tidak dapat dipisahkan satu sama lain; Point of view merupakan posisi pengarang dalam membawakan cerita. Posisi ini biasa berperan langsung atau hanya sebagai orang ketiga sebagai pengamat; Gaya ialah penggunaan bahasa yang berfungsi sebagai penciptaan suatu nada atau suasana serta dialog yang mampu menghidupkan interaksi dengan sesama tokoh; Amanat adalah pesan pengarang terhadap pembaca (pesan dalam sebuah karya sastra selalu positif dan tidak pernah dijumpai suatu amanat negative).

\section{Model Pembelajaran Think Talk Write (TTW)}

Menurut Huda (2013: 218) Think Talk Write adalah strategi yangmemfasilitasi latihan berbahasa secara lisan dan menulis bahasa tersebut dengan lancar. Strategi yang pertama kali diperkenalkan oleh Huinker dan Laughlin ini didasarkan pada pahaman bahwa belajar adalah sebuah perilaku sosial. Strategi Think Talk Write mendorong siswa untuk berfikir, berbicara, dan kemudian menuliskan suatu topik tertentu. Strategi Think Talk Write memperkenalkan siswa untuk memengaruhi dan memanipulasi ide-ide sebelum menuangkannya dalam bentuk tulisan. Ia juga membantu siswa dalam mengumpulkan dan mengembangkan ide-ide melalui percakapan terstruktur.

Huda (2013: 218-219) menyebutkan bahwa tahap-tahap dalam strategi ini sesuai urutan di dalamnya, yakni Thik (berfikir), Talk (berbicara/berdiskusi), Write (menulis).

Menurut Silver dan Smith (melalui Huda, 2013: 219), peranan dan tugasguru dalam usaha mengefektifkan penggunaan strategi Think 
Talk Write adalah mengajukan dan menyediakan tugas yang memungkinkan peserta didik terlibat secara aktif berfikir, mendorong dan menyimak ide-ide yang mempertimbangkan dan memberi informasi terhadap apa yang digali peserta didik dalam diskusi, serta monitor, menilai dan mendorong peserta didik untuk berpartisipasi secara aktif.

Jadi, dalam strategi Think Talk Write terdapat tiga tahap yang membantu pesertadidik untuk dapat aktif mengikuti pembelajaran di kelas, yaitu tahap berpikir, berbicara dan kemudian menuliskannya menjadi tulisan yang kreatif. Dalam tahap berpikir, ada macammacam jenis kegiatan berpikir. De Bono (2007: 252) mengklasifikasikan dua tipe berpikir sebagai berikut.

1. Berpikir vertikal (berpikir konvergen) yaitu tipe berpikir tradisional dan generatif yang bersifat logis dan matematis dengan mengumpulkan dan menggunakan hanya informasi yang relevan.

2. Berpikir pendek/berpikir lateral (berpikir divergen) yaitu tipe berpikir selektif dan kreatif yang menggunakan informasi bukan hanya untuk kepentingan berpikir tetapi juga untuk hasil dan dapat menggunakan informasi yang tidak relevan atau boleh salah dalam beberapa tahapan untuk mencapai pemecahan yang tepat.

De Bono (2007: 252) mendefinisikan berpikir lateral sebagai suatu metode berpikir yang lebih menitikberatkan kepada perubahan konsep dan persepsi. Berpikir lateral dapat menghasilkan ide yang tidak dapat dihasilkan dengan metode berpikir tradisional. Karena berpikir lateral adalah secara berpikir modern dengan melihat masalah dan mendapatkan solusi dari berbagai arah, tidak hanya sama dengan pemikiran konvensional yang berpikir secara vertikal. Berpikir lateral menjadi orang lebih kreatif dan menemukan lebih banyak solusi secara menakjubkan.

Pembelajaran menceritakan isi cerpen menggunakan strategi Think Talk Write dalam penelitian ini akan dirancang dengan langkahlangkah berikut.

1. Pertama, dalam kegiatan mengamati peserta didik diberi sebuah contoh teks cerita pendek. Guru memberikan tugas membaca cerita pendek tersebut kepada peserta didik.

2. Kedua, peserta didik diminta untuk membuat kelompok yang terdiri dari 5 orang. Kemudian diberi kesempatan untuk membicarakan/ mendiskusikan hasil penyelidikan terhadap 
pertanyaan, jawaban, ide-ide dan hal yang tidak dipahami dalam bacaan pada tahap pertama. Setelah itu, peserta didik merefleksikan, menyusun, serta menguji (negosiasi, sharing) ideide dalam kegiatan bercerita. Kemajuan komunikasi siswa akan terlihat pada dialog-dialognya dalam bercerita, baik dalam bertukar ide dengan orang lain ataupun refleksi mereka sendiri yang diungkapkannya kepada orang lain.

3. Ketiga, dalam kegiatan ini peserta didik menuliskan kemungkinan jawaban dan merumuskannya menjadi ide-ide yang menarik untuk dijadikan sebuah teks cerita pendek. Pada tahap ini peserta didik diberikan waktu untuk menuliskan ide-ide menarik menjadi kerangka karangan. Selanjutnya, kalimat-kalimat dalam kerangka dikembangkan menjadi struktur cerita pendek secara lengkap. Tulisan ini terdiri atas orientasi, komplikasi dan resolusi.

4. Keempat, kegiatan selanjutnya guru memerintahkan peserta didik untuk menceritakan kembali isi cerpen di depan kelas, sedangkan peserta didik yang lain diminta memberikan tanggapan. Setelah semua peserta didik bercerita guru membuatrefleksi dan kesimpulan atas materi yang dipelajari. Kemudian menugasi siswa untuk menuliskan kembali hasil yang diceritakan.

\section{Kelebihan Strategi Pembelajaran Think Talk Write}

Kelebihan Think Talk Write menurut Suyatno (2009: 52) diantaranya adalah sebagai berikut:

1. Aktivitas think dapat meningkatkan keterampilan siswa dalam membedakan dan mempersatukan ide yang disajikan dalam teks bacaan melalui aktivitas membaca terlebih dahulu.

2. Aktivitas write dapat meningkatkan keterampilan berfikir dan menulis

3. Pembentukan ide dapat dilakukan melalui proses talking

4. Pemahaman cerpen dapat dibangun melalui interaksi dan konversasi (percakapan) antara sesama individu

5. Talking dapat membantu guru mengetahui tingkat pemahaman siswa dalam memahami isi cerpen.

\section{METODE}

Penelitian ini dilakukan di kelas IX-6 SMP Negeri 1 Selesai tahun ajaran 2016/2017. Metode penelitian yang digunakan adalah 
Penelitian Tindakan Kelas (action research) yang terdiri atas dua siklus. Dimana setiap siklus terdiri atas perencanaan (planning), pelaksanaan (action), pengamatan (observation) dan refleksi (reflection). Peneliti menggunakan hasil tulisan siswa untuk melihat hasil keterampian siswa dalam menceritakan kembali isi cerpen. Kemudian guru menilai keterampilan bercerita siswa dengan meggunakan lembar peniaian yang telah disiapkan sebelumnya. Lembar penilaian keterampilan bercerita siswa oleh peneliti digunakan sebagai instrumen penskoran untuk menentukan tingkat keberhasilan keterampilan bercerita siswa.

Pengumpulan data diambil dengan lembar pengamatan. Tes yang dilakukan dalam penelitian ini adalah test praktik berbicara, yaitu melalui tugas bercerita di depan kelas. Keterampilan siswa dalam menceritakan kembali isi cerpen diolah dengan mengacu pada KKM yang telah ditentutkan yaitu 75 . Indikator keberhasil siswa apabila siswa yang tuntas KKM telah mencapai KKM pada setiap aspekpenilaian sebesar $80 \%$.

\section{HASIL DAN PEMBAHASAN}

1. Hasil

Penelitian tindakan kelas ini dilaksanakan dalam 6 minggu dengan

2 siklus. Pada tahap awal rata-rata perolehan keterampilan menceritakan kembali isi cerpen kelas IX-6 adalah hanya sebesar 60,5. Pada siklus I ini, rata-rata nilai keterampilan menceritakan kembali isi cerpen siswa SMP Negeri 1 Selesai sudah mencapai KKM yaitu 75,2. Persentase ketuntasan siswa dalam menceritakan kembali isi cerpen pada siklus I sebesar 71,9\%. Kemudian pada siklus II, terjadi peningkatan terhadap keterampilan siswa dalam menceritakan embali isi cerpen yaitu rata-rata perolehan siswa sebesar 82,8 dengan persentase ketuntasan sebesar 90,6\%. Angka tersebut menunjukkan bahwa dengan penerapan pembelajaran Think Talk Write, keterampilan siswa kelas IX-6 SMP Negeri 1 Selesai dalam menceritakan kembali isi cerpen dapat mengalami peningkatan.

\section{Pembahasan}

\section{a. Deskripsi Awal Keterampilan Menceritakan Kembali Isi Cerpen Siswa}


Keterampilan awal menceritakan kemabali isi cerpen siswa dilihat darihasil penilaian tes bercerita sebelum dikenai tindakan. Pada tahap ini banyak terdapat kekurangan-kekurangan siswa dalam bercerita. Banyak siswa dalam berujar (melafal) cukup jelas namun masih terpengaruh dialek setempat walaupun suara, dan intonasinya cukup jelas dalam menceritakan isi cerpen. Banyak siswa dalam memilih kata-kata yanng terlalu monoton, belum ada siswa yang bisa menggunakan kata-kata yang variatif. Siswa juga belum bisa menyesuaikan isi cerita sesuai dengan yang diharapkan oleh peneliti. Berdasarkan Tabel1 rata-rata perolehan keterampilan menceritakan kembali isi cerpen kelas IX-6 adalah sebesar 60,5.

\section{b. Deskripsi Keterampilan Menceritakan Kembali Isi Cerpen Siswa Siklus I}

Pada siklus I, rata-rata nilai keterampilan menceritakan kembali isi cerpen siswa keas IX-6 SMP Negeri 1 Selesai Tahun Pelajaran 2016/2017 sudah mencapai KKM yaitu 75,2. Persentase ketuntasan siswa dalam menceritakan kembali isi cerpen pada siklus I, sesuai dengan tabel 4.2 di atas adalah sebesar $71,9 \%$.

Pada siklus I ini, sebagian siswa kelas IX-6 SMP Negeri 1 Selesai pada Aspek pelafalan mengalami peningkatan dibandingkan dengan pratindakan. Siswa-siswa sudah mulai jelas dalam melafalkanfonem, suara jelas dan nyaring, serta intonasinya sudah mulai tampak jelas. Pada aspek kosakata, siswa-siswa sudah mulai menggunakan kata-kata yang tidak monoton, istilah-istilah yang dipergunakan sudah bervariatif.

Pada Aspek struktur, kemampuan siswa dalam aspek tergambar dalam setiap mengawali bercerita dengan ide pokok baru mengawalinya dengan subjek dan setting. Siswa dalam bercerita tidak menyimpang dari isi cerpen, cerita yang dipaparkan mudah dipahami. Alur yang diceritakan sudah runtut sesuai cerpen aslinya dan mulai detil sehingga cerita menjadi menarik untuk disimak. Siswa sudah mulai jarangberhenti karena lupa ide pokok ceritanya. Penjedaan dalam bercerita mulai tepat sehingga keutuhan konteks kalimat menjadi baik sesuai dengan isi cerpen. Sebelum adanya tindakan pada aspek ini banyak dijumpai siswa berhenti bercerita karena penguasaan ide pokoknya kurang baik.

Dan pada aspek gaya (ekspresi) siswa sudah mulai memiliki sikap ekspresif dalam bercerita. Hingga pada aspek Ketreampilan 
mengolah/mengembangkan ide cerita, siswa lebih kreatif dalam pengembangan gagasan yang menjadikan cerita lebih bisa dinikmati siswa lain.

\section{c. Deskripsi Keterampilan Menceritakan Kembali Isi Cerpen Siswa Siklus II}

Pada siklus I, rata-rata nilai keterampilan menceritakan kembali isi cerpen siswa keas IX-6 SMP Negeri 1 Selesai Tahun Pelajaran 2016/2017 sudah mencapai KKM yaitu 75,2. Persentase ketuntasan siswa dalam menceritakan kembali isi cerpen pada siklus I, sesuai dengan tabel 4.2 di atas adalah sebesar 71,9\%. Kemudian pada siklus II, terjadipeningkatan terhadap keterampilan siswa dalam menceritakan embali isi cerpen yaitu rata-rata perolehan siswa sebesar 82,8 dengan persentase ketuntasan sebesar 90,6\%.

Angka tersebut menunjukkan bahwa dengan penerapan strategi Think Talk Write, keterampilan siswa kelas IX-6 SMP Negeri 1 Selesai dalam menceritakan kembali isi cerpen dapat mengalami peningkatan.

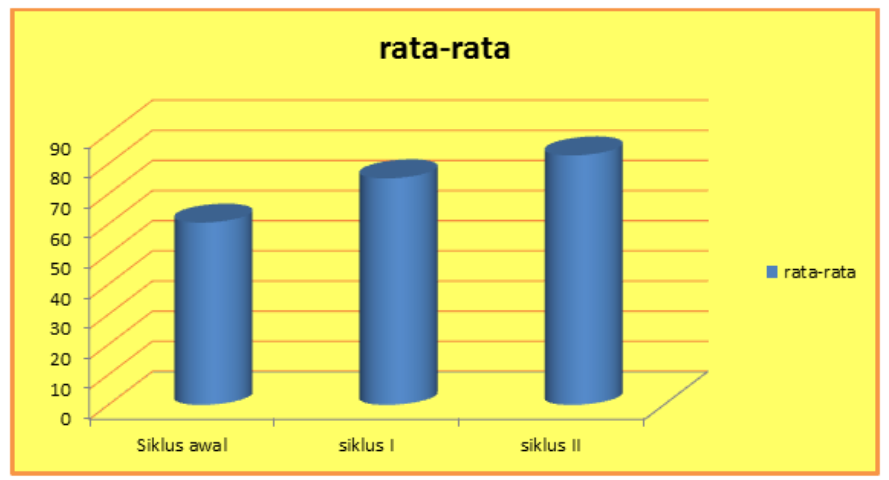

Gambar 1. Rata-rata keterampilan siswa dari tahap awal sampai dengan siklus II

\section{E. SIMPULAN}

\section{Kesimpulan}

Berdasarkan hasil penelitian yang telah dijelaskan pada bab sebelumnya, dapat disimpulkan bahwa strategi pembelajaran Think Talk write dapat digunakan acuan untuk meningkatkan keterampilan berbicara siswa kelas IX-6 SMP Negeri 1 Selesai Tahun Pelajaran 2016/2017. Peningkatan yang terjadi setelah dikenai tindakan. Setelah diterapkan strategi Think Talk Write pada siswa kelas IX-6 SMP 
Negeri 1 Selesai Tahun ajaran 2016/2017. Pada tahap pratindakan skor rata-rata kelas yang diperoleh sebesar 60,6, meningkat pada siklus I menjadi 75,2 dengan persentase ketuntasan siswa sebesar $71,9 \%$.kemudian pada siklus II meningkat lagi menjadi 82,8 dengan persentase ketuntasan sebesar $90,6 \%$.

\section{Saran}

1. Bagi guru Bahasa Indonesia SMP Negeri 1 Selesai sebaiknya memilih strategi pembelajaran yang paling tepat untukpembelajaran bercerita dan dapat memanfaatkan strategi pembelajaranThink Talk Write sebagai salah satu strategi pembelajaran dalampembelajaran bercerita.

2. Bagi siswa, penelitian ini diharapkan dapat membuat siswa untuk lebih aktifdan dijadikan motivasi belajar bercerita sehingga dapat meningkatkanketerampilan bercerita di depan kelas.

3. Bagi pihak sekolah, penelitian ini diharapkan dapat digunakan untukmeningkatkan kualitas belajar mengajar di sekolah.

\section{F. DAFTAR PUSTAKA}

De Bono, E. 2007. Resolusi Belajar. Jakarta: Kaifa.

Huda, M. 2013. Model-model Pengajaran dan Pembelajaran. Yogyakarta: Pustaka Pelajar.

Majid, A. 2008. Perencanaan Pembelajaran, Mengembangkan Standar Kompetensi Guru. Jakarta: Rosda Karya.

Nurgiyantoro, B. 2012. Penilaian Pembelajaran Bahasa. Yogyakarta: BPFE.

Nurgiyantoro, B. 1995. Teori Pengkajian Fiksi. Yogyakarta: Gajah Mada University Press.

Suyatno. 2009. Menjelajah Pembelajaran Inovatif. Jakarta: Masmedia Buana Pustaka.

Tarigan, H.G. 1994. Membaca Sebagai Suatu Keterampilan Berbahasa. Bandung: Penerbit Angkasa.

Tim Penyusun Pusat Bahasa. 2007. Kamus Bahasa Indonesia, Jakarta:

Pusat Bahasa. 